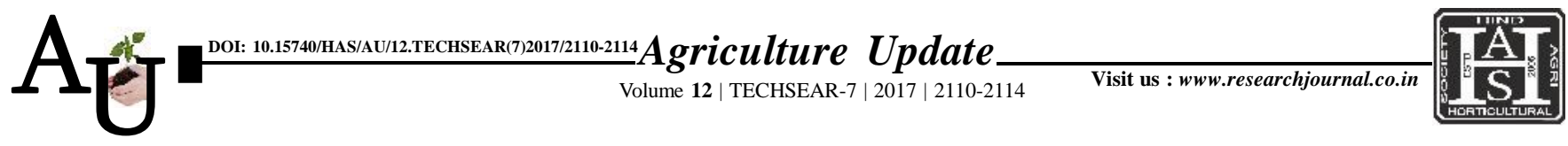

\title{
A CAsE Studv: Agricultural market intelligence-A case study of maize crop price forecasting
}

\section{R. VIJAYA KUMARI, GRAMAKRISHNA,VENKATESH PANASA AND S. KAVIRAJU}

Article Chronicle :

Received :

19.07.2017;

Accepted :

03.08.2017

KEY Words:

Maize crop, ARIMA, ARCH, GARCH

Author for correspondence :

R. VIJAYA KUMARI

Network Project on

Market Intelligence,

Department of

Agricultural Economics,

College of Agriculture,

Professor Jayashankar

Telangana State

Agricultural University,

Rajendranagar,

HYDERABAD

(TELANGANA) INDIA

See end of the article for

authors' affiliations
SUMMARY : The majority of the rural producers are unable to understand and interpret the market and price behavior to their advantages. Hence, market information and intelligence are crucial to enable farmers and traders to make informed decisions about what to grow, when to sell, and where to sell.The price forecasts are made by analyzing the prices of Agricultural Commodities concerned over 15 years using advanced statistical tools like ARIMA, ARCH, GARCH models, comparing the same with prices of futures markets and national and international reports of trade surveys besides conducting state level trade surveys. Under the project price forecasts were made for maize crop twice during Kharif and Rabi seasons for 3 years / 6 seasons from Kharif 2014 to Rabi 2016-17. Thus, a total 12 price forecasts with more than 90 per cent precision were developed and disseminated through various means like university website, university magazine, Vyavasayam, SMS to contact farmers, pamphlets, farmers trainings and meetings, etc.

How to cite this article : Kumari, R. Vijaya, Gramakrishna, Panasa, Venkatesh and Kaviraju, S. (2017). Agricultural market intelligence - A case study of maize crop price forecasting. Agric. Update, 12(TECHSEAR-7) : 21102114; DOI: 10.15740/HAS/AU/12.TECHSEAR(7)2017/2110-2114. 